\title{
板壁等に耐震上の工夫を施した伝統木造架構の実大水平加力実験 A EXPERIMENT ON FULL-SIZE MODELS OF THE WOODEN TRADITIONAL STRUCTURE WITH THE IMPROVED EARTHQUAKE-RESISTANT DEVICES
}

\author{
河内 武*, 貞広 修**, 木村 誠**, 福本敦子**, 近藤一夫*** \\ Takeshi KAWACHI, Osamu SADAHIRO, Makoto KIMURA, \\ Atsuko FUKUMOTO and Kazuo KONDOH
}

\begin{abstract}
Experiments on traditional wooden structures with devices to improve earthquake performance are performed. Devised points are as follows. 1) Kashira-nuki and Nageshi are improved and employed as structural elements. 2) Boards of wooden siding wall, in which are Chikara-nuki and Chikara-ita arranged by turns, is developed. Following things become to be clear as results. 1) The larger the column axial-force becomes to be, strength and stiffeness of Kashira-nuki increase. 2) Nageshi increases strength of structure by 1.5 times in the case with no Nageshi. 3) Wooden siding wall increases strength of structure by 3 times in the case without one.
\end{abstract}

Keywords : Full-size model test, Framed Structure, The Wooden Siding Wall, Nageshi, Traditional Structure 実大実験，軸組構造，板壁，長押，伝統構法

\section{1. はじめに}

近年, $\mathrm{CO}_{2}$ 削減などの環境問題を背景にした木造建築の再評価に伴 ない，日本の伝統木造建築に関する関心も高まってきており，限界 耐力設計法を中心とした構造設計手法の整備も進んできている。し かしながら,伝統木造建築は, 金物を多用する現代の構法に比べて, 十分な接合部の耐力・剛性を確保するのが難しく, 必要な構造的要 求性能を確保するのが困難な部分も多い。

そこで本報では，伝統木造建築の耐震性向上を図るためにいくつ かの独自の工夫を施した架構体 ${ }^{1}$ を考案し, その耐震要素の耐力評 価方法を確立するための実大水平加力実験を実施し，その影響，効 果を調查した。考案した架構では, 柱の傾斜復元力, 貫仕口, 板壁 などの主な耐震要素のうち, これまであまり評価の対象として取り 上げられなかった頭貫と長押の仕口に工夫を凝らし，耐震要素とし て評価しようと試みていること, また, 板壁について, 建築基準法 などに規定されている落とし込み板壁に片側貫を加えることで，耐 震壁としての性能の向上を図っていることが主な特徴である。

これらに関連した既往の研究としては，頭貫については，廻廊架 構の研究の一環として頭貫の機構について考察した菊岡, 西澤らの 研究 ${ }^{2)}$ ，法隆寺金堂の頭貫一柱接合部の縮尺模型実験を実施した丹
羽らの研究 ${ }^{3)}$ など若干の事例があるのみである。長押に関しても構 造部材としての検討例は少なく，長押形状の変遷と構造性能の評価 を行ない補強材としての可能性について考察した佐藤, 藤田らの研 究 ${ }^{4)}$ や，列柱状に間伐材を並べた壁体の横架材として長押のしくみ を利用した白鳥, 小松らの研究 ${ }^{5)}$, 廻廊建築における古代様式の長 押の効果についての静的載荷実験を行なった宮本, 西澤らの研究 ${ }^{6)}$ があるのみで，関連するデータは乏しい。また，板壁については， 建築基準法などに規定されている落とし込夕板壁については，(財) 日本住宅・木材技術センターによる技術解説書 ${ }^{7)}$ の整備をはじめ, さまざまな構造的工夫も提案されているが，本報告に示すような力 貫と力板を交互に配置した形式の板壁の例は見られない。

\section{2. 対象とする架構とその耐震上の特徵}

本論で対象とする伝統木造架構は, 主な耐震要素として, 柱の傾 斜復元力, 貫仕口, 板壁の耐力を期待した架構である。継手・仕口 については, 飛鳥時代から江戸末期までの事例のうちで構造性能上, 最も優れていると思われる中世，特に室町中期の仕口に改良を加え て採用した。また，長押を固定する和釷を除けば主要な構造部には 金物を一切使わずに組みあげている。

\footnotetext{
* 清水建設㮫技術研究所 主任研究員·工修

***清水建設(侏)設計本部 設計長・工修

*** 広島大学大学院工学研究科 准教授. 工博
}

Senior Research Engineer, Institute of Technology, Shimizu Corporation, M. Eng. Senior Structural Engineer, Design Division, Shimizu Corporation, M. Eng. Assoc. Prof., Graduate School of Eng., Hiroshima University, Dr. Eng. 
架構の耐震上の特徵として, 以下の項目が挙げられる。

1）従来はピン接合部としてモデル化され, 構造上はあまり評価の 対象として取り上げられなかった頭貫の仕口にすべり勾配を設け ることで，半剛節接合部としての性能を持たせた。

2）現在では化粧材として使用される長押を本来の耐震要素とし て評価可能な構造要素として採用した。

3）建築基準法などに規定されている落とし込み板壁に力貫を加 えることで，耐震壁としての性能を向上させた。

対象とする架構各部の概略を図 1 に, 次節に示す実大実験で用い た部材の断面寸法を表 1 に示す。頭貫と柱の仕口は, 図 1 (a)に示す ように, 柱頭部を十字状に彫り込夕, そこに相欠き状態に交差させ た頭貫を落とし込むことにより，柱頭部を柱径方向内側に締め付け るためのすべり勾配面を設け, 剛性を高める工夫をした。礎石と柱 脚の仕口は, 図 1 (b) に示すように, 礎石の上面に花崗岩製の半球状 の丸ダボを作り出し, 柱の底部には半球状の凹部を作って納めて, 柱の傾斜を許容し，その復元力を期待した。礎石部分の詳細は図 2 に示す。内法長押と柱の仕口は, 図 1 (c) に示すように, 柱を矩形の 対の長押で挟み込み, 長押の底面は柱に輪薙込み, 上の面には引独 鈷を設けることにより互いに引き寄せて柱を締め付け，側面からは 約六寸の鋳鉄製の和釷を打ち込んで固定し，長押を化粧材ではなく 構造材として働かせる工夫をした。内法貫, 足固貫の仕口は, 図 1 (d)に示すように, 貫を直交させて相欠き状態に組み, 楔締めとした。 板壁の仕口は, 図 1 (e) に示寸ように, 力板と力貫を交互に設けてそ れぞれ $300 \mathrm{~mm}$ 間隔で設置したダボでつなぎ，変形時にダボのせん断 抵抗を働かせた。力板と力貫を交互に設けることにより, 力貫と柱

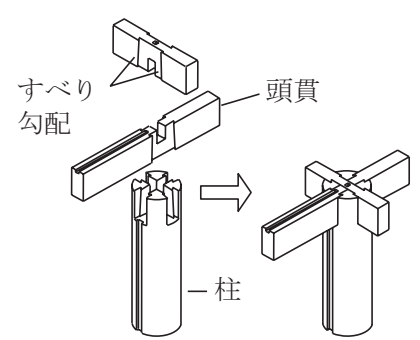

(a) 柱頭

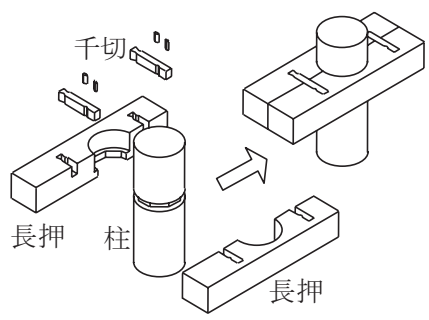

(c) 長押

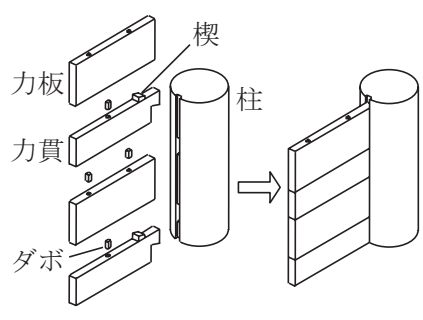

(e) 板壁

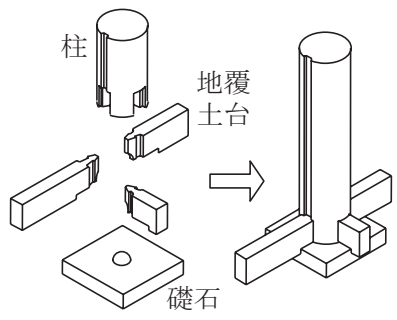

(b) 柱脚

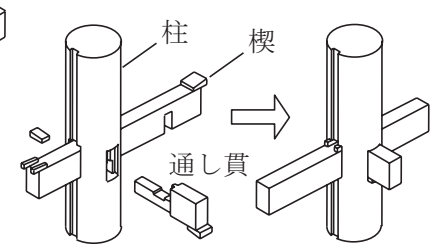

（d）通し貫

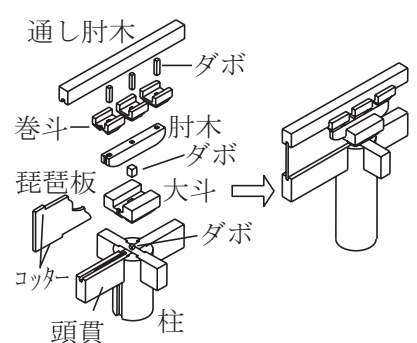

(f) 組物
図 1 架構各部の概略
の間のめり込み抵抗を期待した。組物周辺については, 図 1 (f) に示 すように, 組物と間斗束の間には大斗と柱をつなぐダボのせん断耐 力の不足を補うため琵琶板を嵌め込み, 琵琶板と通し肘木の双方, および琵琶板と頭貫の双方にそれぞれ琵琶板の水平変位を押さえる 段差（コッター）を設けている。

\section{3. 実大水平加力実験の概要}

試験体は，中規模社寺建築の標準的な架構の一層一スパン分を原 寸大で模擬したものであり，各部の形状および寸法は，図 1 および 表 1 に示した通りである。架構は，柱中心間の距離 $2700(\mathrm{~mm})$, 柱脚 から頭貫頂部までの高さ $3000(\mathrm{~mm})$ を基本としている。図 3 および表 2 に試験体の一覧を, また, 表 3 には各試験体の比較項目を示寸。 柱脚部の礎石の周辺はコンクリートで固めて鋼製の型枠ごと加力フ レームに固定している。なお，使用した木材のうち，柱・地覆土台 はす心゙ての試験体で共通のものを転用し, 頭貫 - 内法貫・足固貫 • 楔・板壁のダボは試験体ごとに新たな部材と交換した。板壁の力板・ 力貫は Type 7, 8 およびType9〜12 でそれぞれ共通のものを転用した が，ダボを挿入するホゾ穴は試験体ごとに別のものを使用した。ま た，使用する木材は，長押を固定する引独鈷と板壁のダボのみ欅材 で，他は国産の桧材とした。

加力は, 図 4 に示寸加力装置を用いて, 軸力載荷用の油圧ジャッ キ（軸力ジャッキ）で柱に指定した軸力を加えながら押し引き両動 の串型油圧ジャッキ（水平ジャッキ）により水平方向に正負交番繰 返し載荷を行なった。軸力は一定の值を保持するよう軸力ジャッキ で制御しながら与えた。水平力は Type 8 以外は頭貫位置, Type8 の み通し肘木に加えた。図 5 に加力サイクルを示寸。このうち, +13 サイクルの加力は Type8, 11 の試験体についてのみ実施した。軸力は, 柱 1 本あたり $44.1 \mathrm{kN}$ を基準とした。ただし, 軸力の影響を把握する ために, Type1,2の試験体については, 図 5 (a) に示すように, 各 繰り返しサイクルごとに軸力の值を 0.0.29.4, 44.1，58.8 (kN) と変 化させている。また, Type 8, 11 の試験体について実施した+13 サイ クルの場合についてのみ, 柱脚の浮き上がり防止のため柱 1 本あた

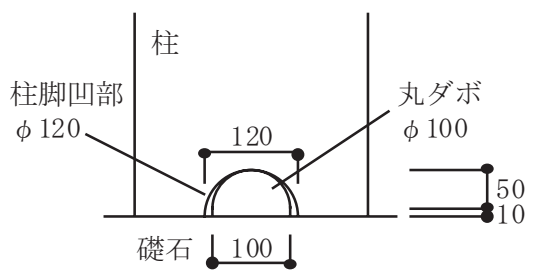

図 2 礎石部分の詳細

表 1 使用した部材の寸法

\begin{tabular}{c|c|c}
\hline 部材 & 成 $(\mathrm{mm})$ & 幅 $(\mathrm{mm})$ \\
\hline \hline 頭貫 & 210 & 100 \\
\hline 通し貫 & 180 & 90 \\
\hline 力貫 & 180 & 45 \\
\hline 力板 & 258.75 & 45 \\
\hline ダボ & 21 & 21 \\
\hline 通し肘木 & 120 & 100 \\
\hline 柱(直径) & \multicolumn{2}{|c}{300} \\
\hline
\end{tabular}




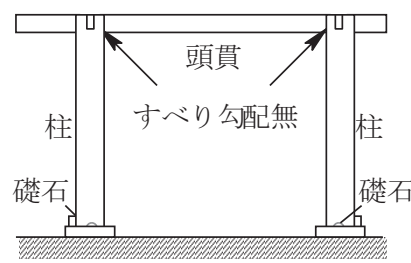

(a) Type1

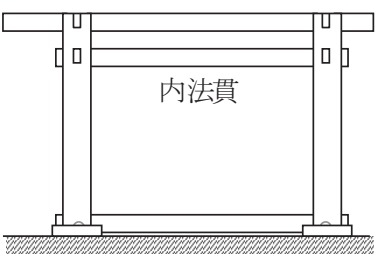

(e) Type5

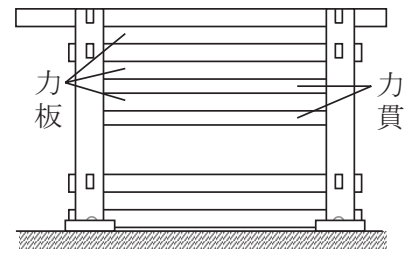

板壁のダボ間隔 $300 \mathrm{~mm}$

(i) Type 9

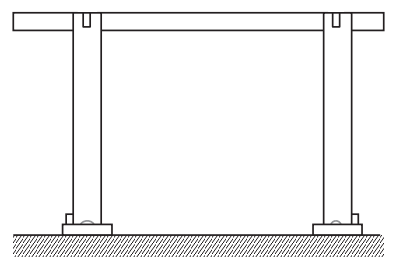

(b) Type2

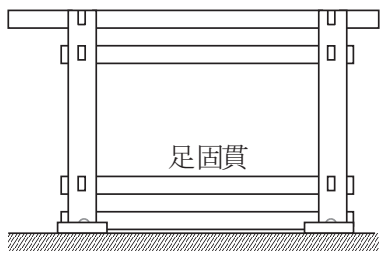

(f) Type6

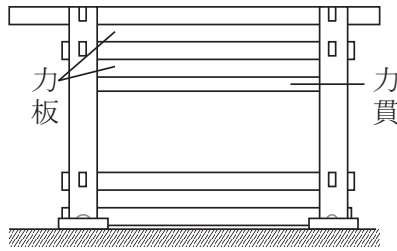

板壁のダボ間隔 $300 \mathrm{~mm}$

(j) Type10

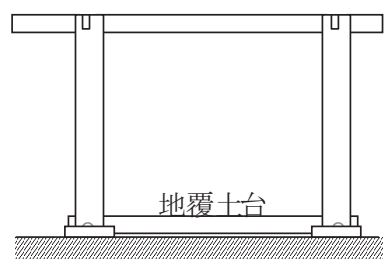

(c) Type3

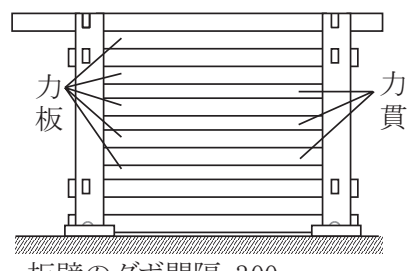

板壁のダボ間隔 $300 \mathrm{~mm}$

(g) Type7

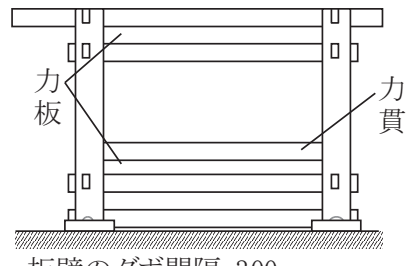

(k) Type11

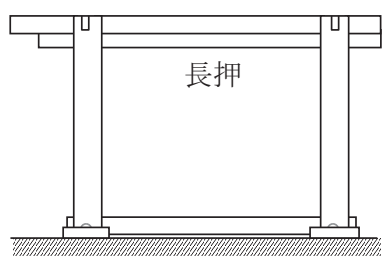

(d) Type4

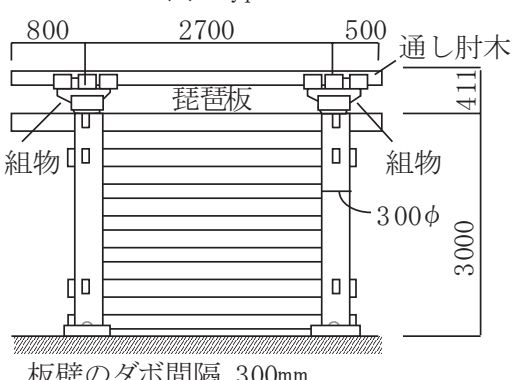

板壁のダボ間隔 $300 \mathrm{~mm}$

(h) Type8

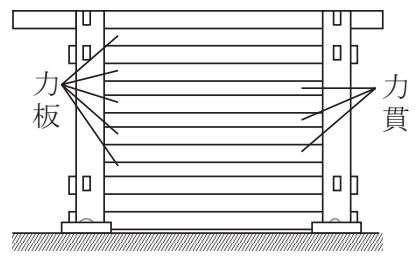

板壁のダボ無し

(I) Type12

図 3 試験体一覧

表 2 試験体一覧

\begin{tabular}{c|c|c|c|c|c|c|c}
\hline \multirow{2}{*}{ 試験体 } & \multicolumn{7}{|c}{ 構成部材 } \\
\cline { 3 - 8 } & 頭貫 & 内法 & 足固 & 地覆 & 長押 & 板壁 & $\begin{array}{c}\text { 組物 } \\
\text { 等 }\end{array}$ \\
\hline \hline Type1 & $\bigcirc^{* 11}$ & - & - & - & - & - & - \\
\hline Type2 & $\bigcirc$ & - & - & - & - & - & - \\
\hline Type3 & $\bigcirc$ & - & - & $\bigcirc$ & - & - & - \\
\hline Type4 & $\bigcirc$ & - & - & $\bigcirc$ & $\bigcirc$ & - & - \\
\hline Type5 & $\bigcirc$ & $\bigcirc$ & - & $\bigcirc$ & - & - & - \\
\hline Type6 & $\bigcirc$ & $\bigcirc$ & $\bigcirc$ & $\bigcirc$ & - & - & - \\
\hline Type7 & $\bigcirc$ & $\bigcirc$ & $\bigcirc$ & $\bigcirc$ & - & $\bigcirc^{* 2)}$ & - \\
\hline Type8 & $\bigcirc$ & $\bigcirc$ & $\bigcirc$ & $\bigcirc$ & - & $\bigcirc^{* 2)}$ & $\bigcirc$ \\
\hline Type9 & $\bigcirc$ & $\bigcirc$ & $\bigcirc$ & $\bigcirc$ & - & $\bigcirc^{* 3)}$ & - \\
\hline Type10 & $\bigcirc$ & $\bigcirc$ & $\bigcirc$ & $\bigcirc$ & - & $\bigcirc^{* 4)}$ & - \\
\hline Type11 & $\bigcirc$ & $\bigcirc$ & $\bigcirc$ & $\bigcirc$ & - & $\bigcirc^{* 5}$ & - \\
\hline Type12 & $\bigcirc$ & $\bigcirc$ & $\bigcirc$ & $\bigcirc$ & - & $\bigcirc^{* 6}$ & - \\
\hline
\end{tabular}

\section{○：部材あり}

一：部材なし

*1）す心゙り勾配なし

(Type1のみ)

*2）力板 $\times 5$, 力貫 $\times 3$

ダボ間隔 $300 \mathrm{~mm}$

全面壁夕イフ

*3）力板 $\times 3$, 力貫 $\times 2$ ダボ間隔 $300 \mathrm{~mm}$ 全面壁夕イプ

$* 4 ）$ 力板 $\times 2$, 力貫 $\times 1$

ダボ間隔 $300 \mathrm{~mm}$

垂壁夕イ゚ （板壁上側）

$* 5$ ）力板 $\times 2$, 力貫 $\times 1$

ダボ間隔 $300 \mathrm{~mm}$

腰壁タイプ（板壁下側）

*6) 力板 $\times 5$, 力貫 $\times 3$

ダボなし, 全面壁タイ
表 3 比較項目

\begin{tabular}{c|c}
\hline 比較項目 & 対象試験体 \\
\hline \hline すべり勾配の有無 & Type1, 2 \\
\hline 地覆土台の有無 & Type2, 3 \\
\hline 長押の有無 & Type 3,4 \\
\hline 内法貫の有無 & Type3, 5 \\
\hline 足固貫の有無 & Type5, 6 \\
\hline 組物, 琵琶板の有無 & Type7, 8 \\
\hline 板壁の位置 & Type10,11 \\
\hline 板壁の数量 & Type6, 7, 9, 10 \\
\hline 板壁ダボの有無 & Type7, 12 \\
\hline
\end{tabular}

変形角 Type8,11のみ

軸力

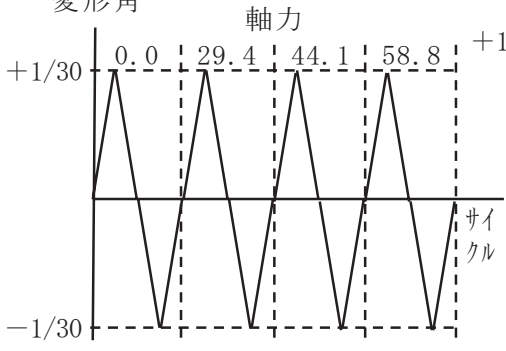

(a) Type1, 2
変拜 - . - 耐力低下まで-13

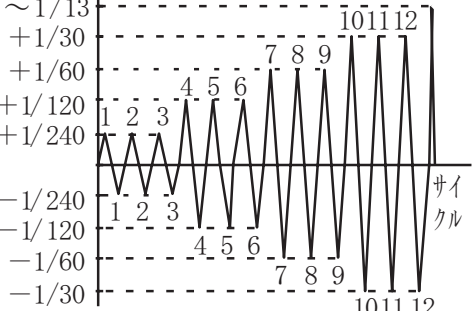

(b) Type3 12

図 4 加力装置概略

図 5 加力サイクル 
り $88.3(\mathrm{kN})$ の軸力とした。なお, 基本とした軸力 $44.1(\mathrm{kN})$ は, 銅板 など金属莫きの屋根荷重の平均的な柱 1 本あたりの值, $29.4(\mathrm{kN})$ は, 蒠・桧皮莫きなど軽めの屋根, $58.8(\mathrm{kN})$ は, 瓦莫きなど重めの屋根 を想定した荷重である。荷重はジャッキに取り付けたロードセルを 用いて測定した。変位は水平方向・鉛直方向について電気式変位計 を用いて測定した。変位計はいずれも加力フレームの外側に設けた 計測用フレームからの絶対変位を測定した。なお, 次節以降の展開 における変形角 : R は, 頭貫中心位置の水平方向変位を用いて算定 している。

\section{4. 実験結果とその考察}

実験は, 前述のように, 頭貫 -内法貫 - 足固貫・楔・板壁のダボ を試験体ごとに交換し（柱・地覆土台は転用）, 順次試験体を組み 替えながら, Type $6 \rightarrow$ Type $5 \rightarrow$ Type $3 \rightarrow$ Type $4 \rightarrow$ Type $7 \rightarrow$ Type $2 \rightarrow$ Type 1 $\rightarrow$ Type $8 \rightarrow$ Type $9 \rightarrow$ Type $10 \rightarrow$ Type $11 \rightarrow$ Type $12 ， と い う$ 順で実施した。 全試験体に共通する破壊状況を示寸と，以下のようになる。

1) Type1 以外のすべり勾配を有する試験体では, 右柱頭の直交方 向頭貫の下端右側に, 加力前より幅 $4.5(\mathrm{~mm})$ 程度の割れが生じ ていたが, 加力開始時から各サイクルのピーク変形時まで割れ幅 ほとんど変化しなかった。これに対し，すべり勾配のない Type1 では，この割れが，変形角 $\mathrm{R}= \pm 1 / 30 （ \mathrm{rad} ）$ のイクルのピーク 変形付近で約 $12(\mathrm{~mm})$ まで開き, これに伴い, 加力直交方向の頭 貫も手で動かせるほどガ夕ついた。これは，すべり勾配がないた めに他の試験体に比べて柱頭と頭貫が一体化していないためと思 われる（写真 1 )。

2）内法貫，足固貫，地覆土台を有し，これらに楔を打ち込む Type1, 2 以外の試験体では, 変形角 $\mathrm{R}= \pm 1 / 30(\mathrm{rad})$ のサイクルの ピーク変形付近になると, 内法貫, 足固貫, 地覆土台の加力方向 の楔が手で取りはずせるほどにゆるみ，楔の繊維直交方向への柱 のめり込みも大きくなった。

このほか, 試験体ごとの特記事項を実験順に挙げると, 以下のよ うになる。

3) Type4 の試験体では, 長押に大きな損傷は見られず, 設置した 契，楔，和釷にもゆるみや抜け出しは見られなかった。

4) Type7 の試験体では, 頭貫直下のスパン中央付近のすきまから 板壁に設置したダボを見ると，ダボが穴を広げながら傾き，ダボ

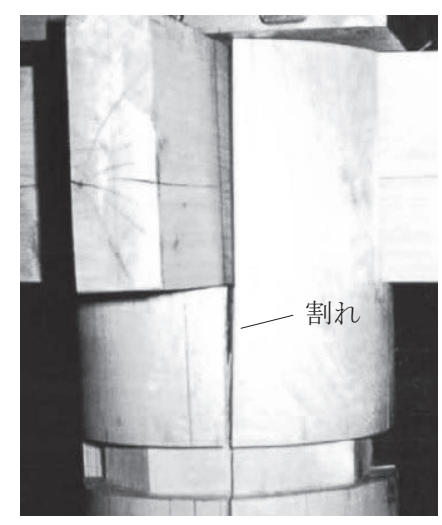

(a) Type 1 写真 1

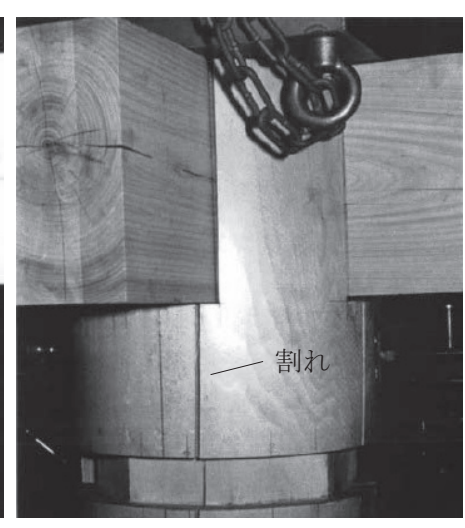

(b) Type2
自身も変形していた。また, 加力終了後に解体した後のダボを見 ると，激しいせん断変形が生じていた。

5) Type8 の試験体では, 加力中, 組物, 琵琶板, 間斗束, 通し时 木には特に大きな変化は見られなかったが，右側の琵琶板のコッ ターに割れが生じた。加力終了後に解体した後のダボを見ると, Type7 と同様, 激しいせん断変形が生じていた。また, 変形角 $\mathrm{R}=$ $\pm 1 / 30(\mathrm{rad})$ のイクルのピーク変形の少し手前で柱脚の浮き上 がり（正加力時には左柱脚, 負加力時には右柱脚）が生じた。こ れは，加力点を頭貫ではなく通し肘木の位置まで上げたためと思 われる。

6) Type11の試験体では, +13 Cycle の途中（変形角 $\mathrm{R}=+1 / 30(\mathrm{rad})$ を越えたあたり）で左側内法貫の接合部の端部に大きな損傷が生 じ（写真 2 参照），これに伴い，荷重值も大きく低下した。最終 状況では, 左右柱頭に 1 ケ所ずつ破損が生じていた。

7）Type12の試験体では, 荷重值が他の試験体に比べてかなり低 いが，これは，その前に実施したType11の+13 Cycleにおける 試験体の損傷の影響があるものと思われる。

8）全ての試験終了後に試験体を解体して観察した所, 楔（内法 貫・足固貫・板壁），内法貫・足固貫の接合部内のわたりあご部 分, 力貫と柱の接触部分 (力貫の繊維方向が柱の繊維直交方向へ めり込む部分）でのめり込み跡が特に顕著であったが，接合部以 外の部材断面に割れなどの大きな損傷は見られなかった。

図 6 に, 各試験体の水平荷重: $\mathrm{P}$ と変形角: R の関係を示す。また, 表 4 には, 各試験体の $\mathrm{R}= \pm 1 / 60,1 / 30 （ \mathrm{rad} ）$ における水平荷重 $\mathrm{P} の$ 一覧を示す。

履歴ループの形状については, いずれの試験体ともスリップ性状 を示すが，図 6 (a)〜 (f)，(1)に示される，板壁のないType1〜6 およ び板壁のみでダボのない Type12 では, ピーク変位で荷重方向が反転 した後, 直ちに荷重がゼロ付近まで減少するのに対し, 図 $6(\mathrm{~g}) \sim(\mathrm{k})$ に示される，板壁とダボを有する Type7〜11 では，荷重反転後に若 干だが荷重を保持しながら徐々に荷重が減少する，丸みをおびた履 歴ループとなっている。ただし，板壁の枚数が少ない Type10, 11 で は，変形角 $\mathrm{R}=1 / 240 \sim 1 / 120(\mathrm{rad})$ 付近までは Type1〜 6, 12 に近い履 歴ループ形状を示し, 変形が進むに従って Type7, 8 に近い履歴ルー プ形状に移行する傾向が見られる。板壁を有するがダボのない Type12では図 6 (1)に示されるように, Type1〜6,12 に近い履歴ルー

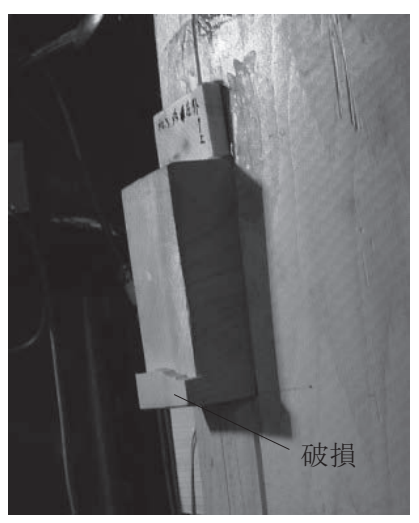

写真 2 Type11 の損傷 $(\mathrm{R}=+13$ Cycle $)$ プ形状であることから，これ らの履歴ループ形状の違いに はダボの有無が大きく影響し, Type7〜11 では除荷時のダボ の抵抗が大きいものと考えら れる。

漸増振幅の繰り返し載荷を 行なった Type3〜12 における 同一変形量での耐力低下につ いては, 繰返しの 1 回目と 2 回目の間で比較的耐力低下が 大きいが, $\mathrm{R}= \pm 1 / 30(\mathrm{rad})$ の変 形までは約 $5 \%$ と小さい。

軸力を変化させた Type1, 


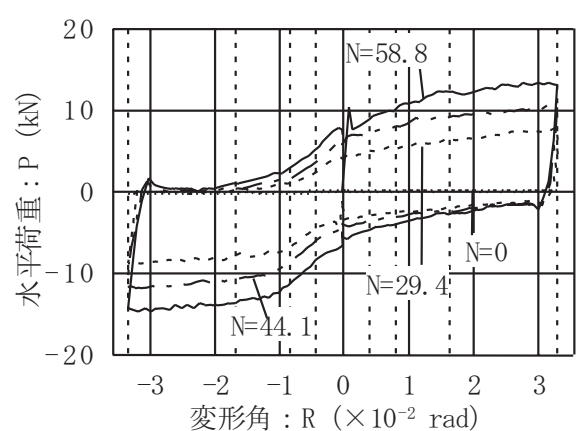

(a) Type 1

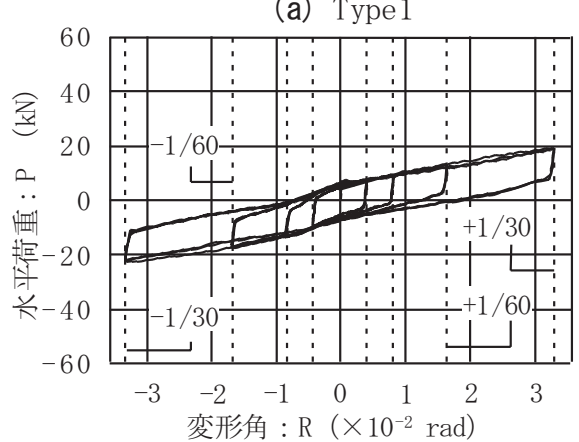

(d) Type 4

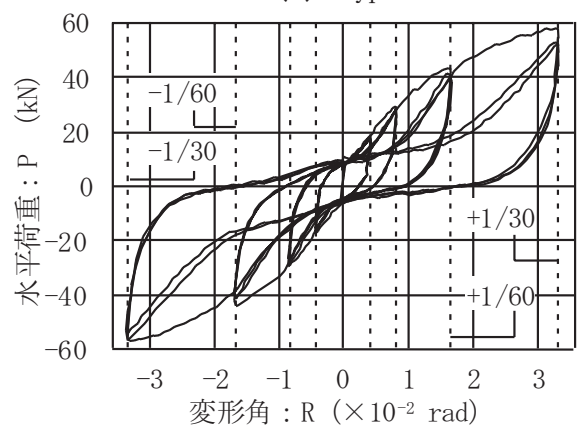

(g) Type7

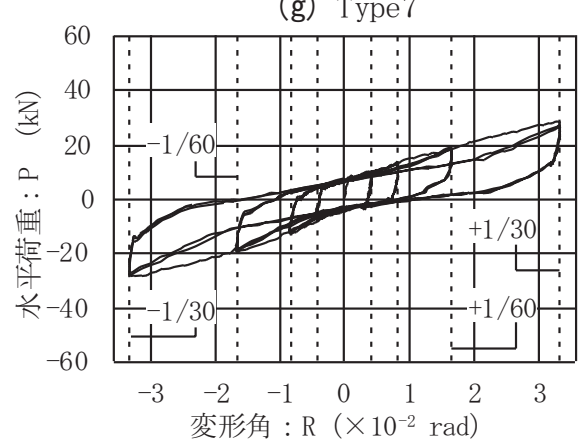

(j) Type 10

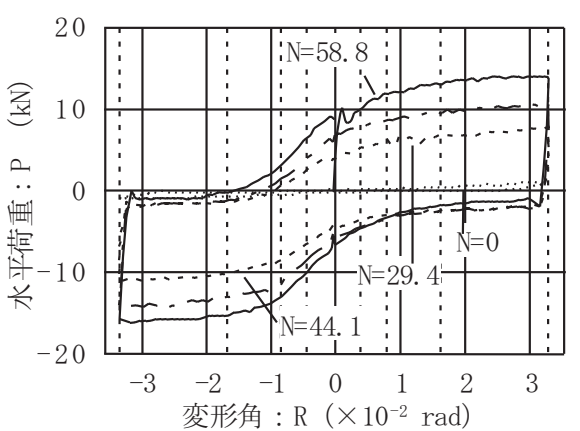

(b) Type 2

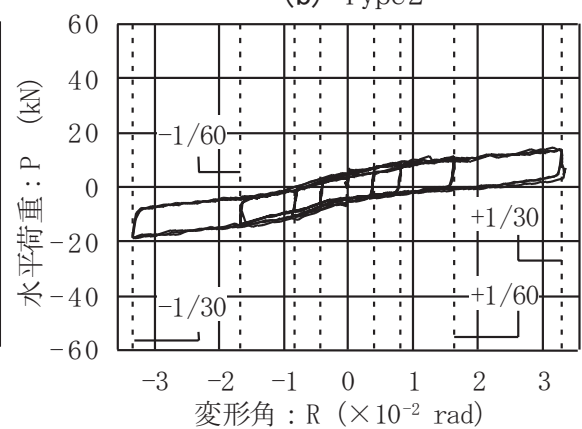

(e) Type 5

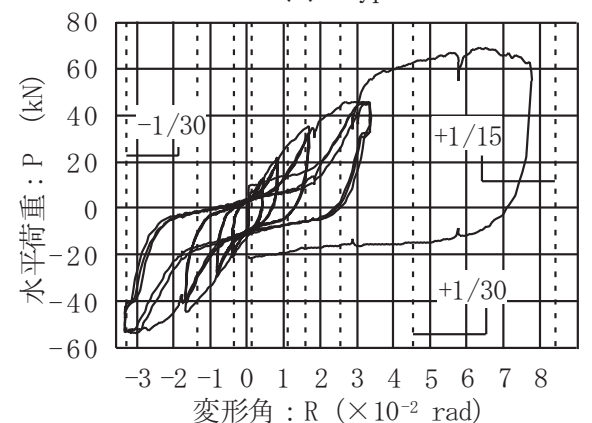

(h) Type 8
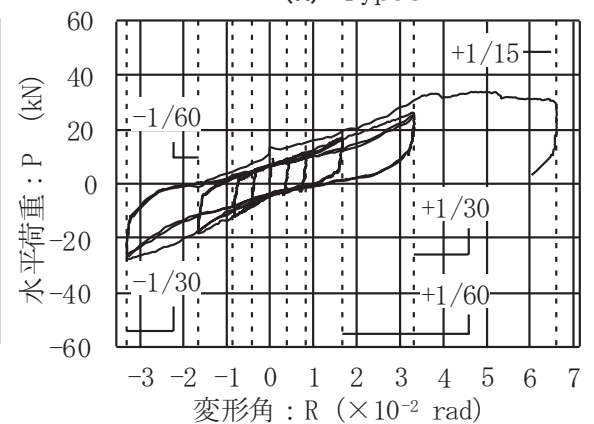

(k) Type 11

図 6 荷重一変形関係

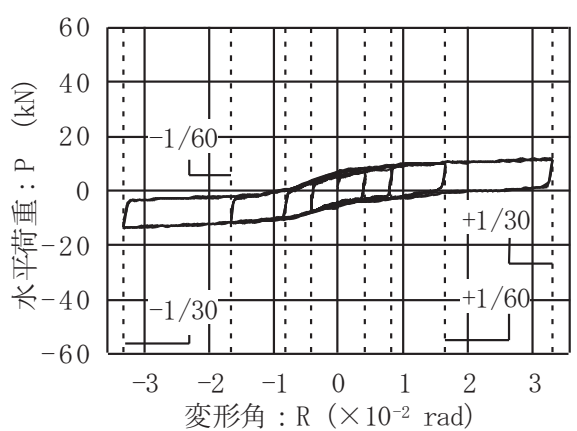

(c) Type 3

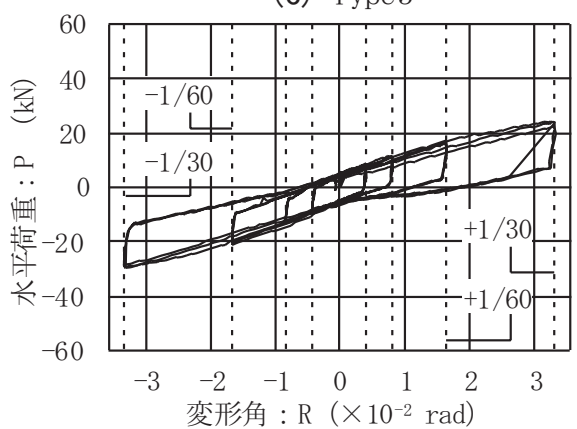

(f) Type6

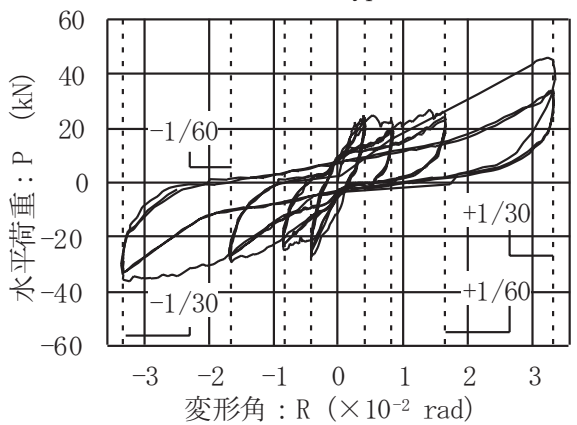

(i) Type 9

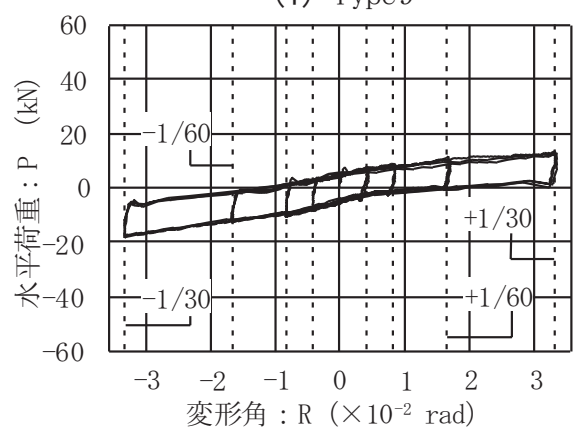

(I) Type 12

表 4 水平荷重值

\begin{tabular}{|c|c|c|c|c|c|c|c|c|c|c|c|c|c|c|c|c|c|}
\hline \multirow{2}{*}{ 試験体 } & \multirow{2}{*}{$\begin{array}{c}\text { 軸力 } \\
(\mathrm{kN})\end{array}$} & \multicolumn{4}{|c|}{ 水平荷重 $(\mathrm{kN})$} & \multirow{2}{*}{ 試験体 } & \multirow{2}{*}{$\begin{array}{c}\text { 軸力 } \\
(\mathrm{kN})\end{array}$} & \multicolumn{4}{|c|}{ 水平荷重 $(\mathrm{kN})$} & \multirow{2}{*}{ 試験体 } & \multirow{2}{*}{$\begin{array}{c}\text { 軸力 } \\
(\mathrm{kN})\end{array}$} & \multicolumn{4}{|c|}{ 水平荷重 $(\mathrm{kN})$} \\
\hline & & $+1 / 60$ & $-1 / 60$ & $+1 / 30$ & $-1 / 30$ & & & $+1 / 60$ & $-1 / 60$ & $+1 / 30$ & $-1 / 30$ & & & $+1 / 60$ & $-1 / 60$ & $+1 / 30$ & $-1 / 30$ \\
\hline \multirow{4}{*}{ Type1 } & 0.0 & 0.2 & -0.1 & 0.2 & -0.2 & Type3 & 44.1 & 10.4 & -11.5 & 11.0 & -13.5 & Type11 & 44.1 & 16.7 & -18.6 & 26.1 & -27.8 \\
\hline & 29.4 & 6.1 & -7.3 & 7.7 & -8.4 & Type4 & 44.1 & 13.3 & -16.7 & 18.9 & -22.0 & Type 12 & 44.1 & 11.2 & -12.7 & 13.5 & -17.4 \\
\hline & 44.1 & 9.2 & -10.2 & 10.4 & -11.4 & Type5 & 44.1 & 11.1 & -13.1 & 13.2 & -17.4 & & & & & & \\
\hline & 58.8 & 12.2 & -13.3 & 12.9 & -13.9 & Type6 & 44.1 & 16.8 & -21.0 & 24.1 & -29.0 & & & & & & \\
\hline \multirow{4}{*}{ Type2 } & 0.0 & 0.4 & -0.7 & 1.1 & -0.9 & Type7 & 44.1 & 43.3 & -44.1 & 58.2 & -56.3 & & & & & & \\
\hline & 29.4 & 6.5 & -9.7 & 7.7 & -10.6 & Type8 & 44.1 & 34.9 & -43.7 & 44.4 & -51.2 & & & & & & \\
\hline & 44.1 & 9.5 & -12.7 & 10.3 & -13.7 & Type9 & 44.1 & 25.6 & -28.7 & 44.0 & -34.0 & & & & & & \\
\hline & 58.8 & 12.8 & -14.6 & 13.6 & -15.4 & Type10 & 44.1 & 19.0 & -19.5 & 28.5 & -28.3 & & & & & & \\
\hline
\end{tabular}


Type2 における, 軸力の影響については, 図 6 (a), (b)に示したよう に, 軸力が大きいほど架構全体の耐力も増加する傾向が見られ, こ うした傾向は, 丹羽らによる実験結果 ${ }^{3)}$ とも一致する。

図 7 (a)-(g) には, 構成部材の効果を明らかにするために, 表 3 に 示した比較項目ごとに包絡線を比較したものを示す。

すべり勾配については, 図 7 (a)に示した Type1, 2 の比較により, すべり勾配のない Type1 でも直交方向の頭貫が効いたため, いずれ の軸力についてもさほど大きな差は生じないが，す心゙り勾配ありの 方が $\mathrm{R}= \pm 1 / 30(\mathrm{rad})$ で最大 $1 \sim 2$ 割程度耐力は増加する。また, 写 真 1 にも示した通り, 右柱頭の直交方向頭貫の下端右側の割れの開 き具合が Type1 ではその他の試験体に比べて大きくなる現象が見ら れたことから，頭貫にすべり勾配を設けることにより柱頭と頭貫が より一体化する効果が期待できることがわかる。

地覆土台の効果については, 図 7 (b) に示した Type2, 3 の比較に より, 正加力時は地覆土台のある Type 3 が, 負載荷時は地覆土台の ない Type2 が若干ではあるが耐力的に上回っているものの, その差 は約 1 割弱と小さく，地覆土台の効果は小さいと言える。

長押の効果については, 図 7 (c)に示した Type 3,4 の比較により, 長押のある Type 4 では変形角 $\mathrm{R}= \pm 1 / 120(\mathrm{rad})$ 付近から耐力が増加し,
長押なしの場合との差も変形が大きいほど大きくなる。長押のある Type4 では, 長押のない Type3 に比べて, 変形角 $\mathrm{R}= \pm 1 / 120$ (rad) で 約 2 割強, 変形 $\mathrm{R}= \pm 1 / 60(\mathrm{rad})$ で約 5 割強, 変形角 $\mathrm{R}= \pm 1 / 30(\mathrm{rad})$ で約 6〜 7 割の耐力増加となっており , 長押の効果は大きいと言える。 通し貫 (内法貫, 足固貫)については, 図 7 (d) に示した Type3, 5, 6 の比較により, 通し貫が増えるに従って耐力も増加し, 通し貫がな い Type3 と内法貫のみ設けた Type5 を比較すると, 変形角 $\mathrm{R}= \pm$ 1/60( $\mathrm{rad})$ を越えるあたりから Type5 の耐力が約 $2 \sim 3$ 割増加して いる。また, 内法貫のみの Type5 と内法貫・足固貫を有する Type6 とを比較すると, 変形角の小さい段階から, 約 7 割耐力が増加して いる。

組物については, 図 7 (e)に示した Type7, 8 の比較より, 変形が進 むにつれ，組物のない Type7 の方が耐力が増加するが，その差は概 ね 1 割未満と小さい。組物のある Type 8 では, 変形角 R=1/37 (rad) 付近で耐力が頭打ちになっているが, これは, 柱脚の浮き上がり（正 加力時には左柱脚, 負加力時には右柱脚) に対応している。Type7 に比べて Type8 では加力点が組物の分だけ高くなっており，このた め水平荷重によるモーメントが大きくなり, 柱脚の浮き上がりが生 じたものと思われる。なお，参考のために記せば，Type8 の実験で

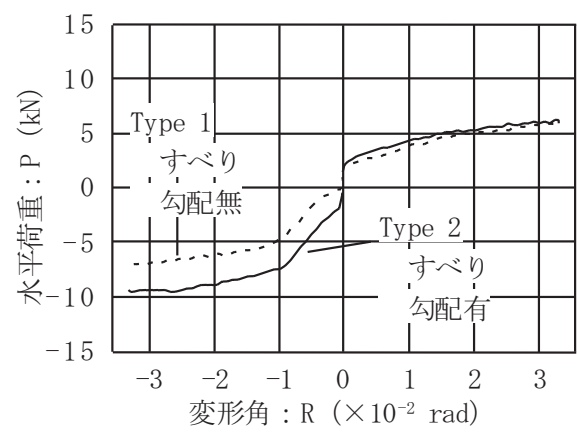

(a) すべり勾配の有無（軸力 $44.1 \mathrm{kN}$ )

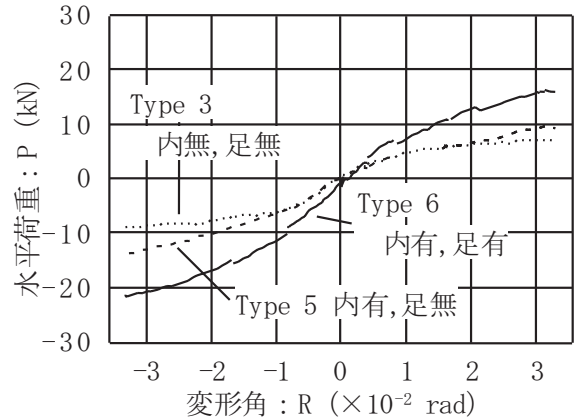

(d) 通し貫の有無

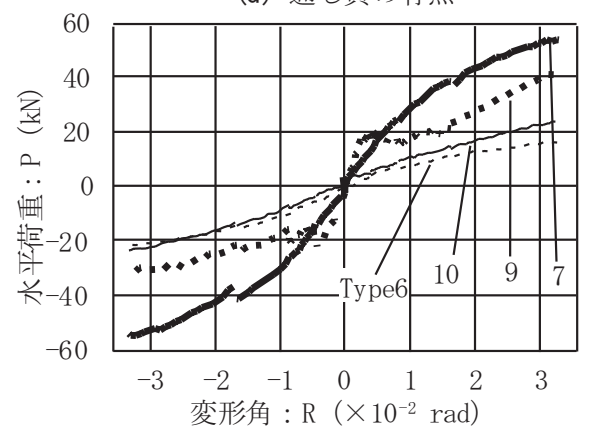

(g) 板壁の数量

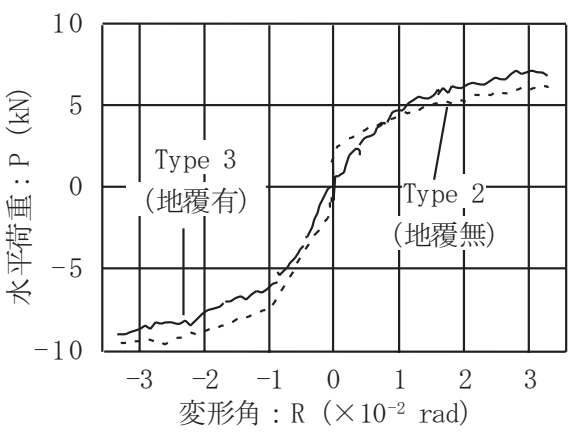

(b) 地覆土台の有無

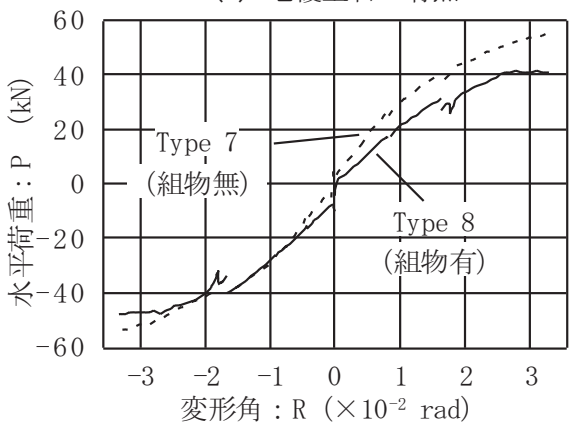

(e) 組物の有無

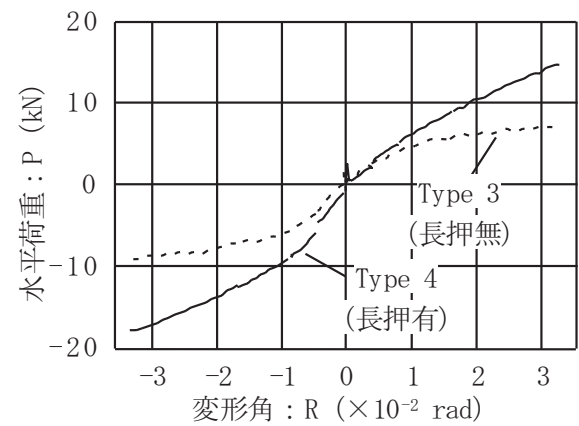

(c) 長押の有無

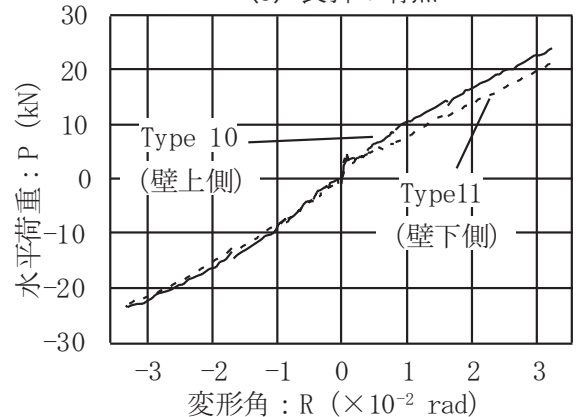

(f) 板壁の位置 
は, +13 サイクルの載荷においては, 軸力を倍の $88.26 \mathrm{kN}$ にてい るため, 柱脚の浮き上がりは起こらず, 板壁のダボの損傷により, 変形角 $\mathrm{R}=1 / 15.5(\mathrm{rad})$ 付近で耐力が低下した（図 $6(\mathrm{~h})$ 参照）。

図 7 (f)の板壁の数量が同じで位置のみ異なる Type10,11 の比較 では, 板壁が上側にある垂れ壁タイプの Type 10 よりも下側にある腰 壁タイプの Type11 の方がわずかに耐力が落ちているようにも見受 けられるが, Type11 の加力順が Type10 の後で, ダボのホゾ穴以外 の部材は Type10 でのものをそのまま転用したために試験体全体が 疲弊していたことと合わせて考えれば，その差はほとんどないもの と見なしてよく, 板壁の枚数が同じならば架構全体の性状もほぼ同 じとみて差し支えないものと思われる。

板壁の数量については, 図 7 (g) に示した Type6, 7, 9, 10 の比較よ り, 板壁の枚数が増えるに従って剛性・耐力が増加する傾向が見ら れる。図 8 (a), (b) には, こうした傾向をより明確にするために, 各 試験体のダボの本数および板の枚数（力板と力貫の枚数の合計）と 各変形角の第 1 回目の載荷時のピーク荷重值との間の関係を示す。 ピーク荷重值は正載荷時と負載荷時の值の平均值としている。なお, ダボの配置間隔はいずれの試験体とも同じであり, ダボの本数と板

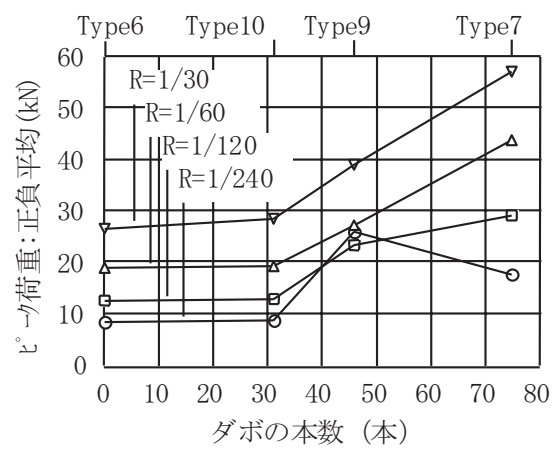

(a) ダボの本数による比較

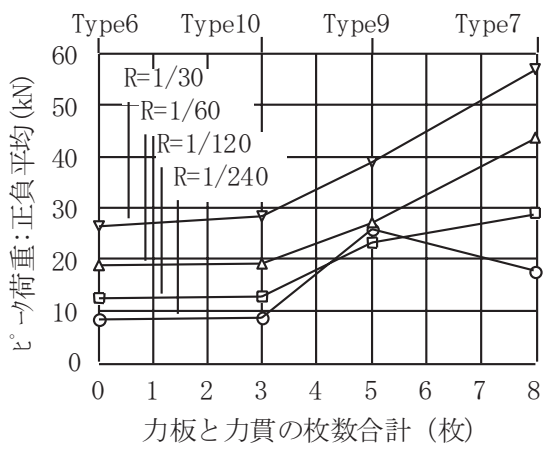

(b) 力板と力貫の枚数による比較
の枚数は概ね比例する。変形の小さい $\mathrm{R}=1 / 240(\mathrm{rad})$ 時の Type9 に若 干の乱れが見られるものの, 板壁の数量が増加するほど剛性・耐力 はともに上昇し，その効果も大きくなることがわかる。

\section{5. 部材のモデル化と弾塑性解析}

限界耐力設計法などで必要となる骨組解析に用いることを想定し, 比較的需要が高いと思われる板壁を有寸る架構について, そのモデ ル化と弾塑性解析を実施した。

解析は，実験の加力サイクルに合わせた繰返載荷で行ない，柱の 軸力は左右の柱頭位置に一定值として与えた。また, 各構造部材の モデル化は以下とした。

頭貫一柱接合部：頭貫・柱の本体は各々はり柱要素とした。接合 部については，柱と頭貫のみで構成されるType1,2の実験結果より， すべり勾配なし・軸力ゼロの場合はほぼピン状態だが，これにすべ り勾配が加わると若干の剛性が付加され, さらに軸力が加わると頭 貫が押さえ付けられることで概社軸力の大きさに比例して接合部の 剛性も増大寸る傾向が見られた。そこで, 頭貫一柱接合部について は, 単純なピン接合部ではなく, 頭貫の抜け出しが柱の軸力によっ て押さえ付けられる効果を半剛節接合Bi-Linear回転バネに理想化 し，その弾性剛性（：KR），降伏モーメント（：My）を軸力（：N） の関数として, 以下のように設定した。

$\mathrm{KR}(\mathrm{N})=\alpha(\mathrm{N}) \cdot \mathrm{KR} 0+\mathrm{KR} 1$

My $(\mathrm{N})=\alpha(\mathrm{N}) \cdot$ My 0

ここに, KR0は文献8)による通し貫一柱接合部の回転バネの弾性剛 性, My 0 は文献8)による通し貫一柱接合部の回転バネの降伏モーメン 卜，KR1は寸べり勾配により付加される剛性，また， $\alpha$ は次式で与え られる軸力の効果を表わす係数である。

$\alpha(\mathrm{N})=\mathrm{N} / \mathrm{N} 0(0 \leqq \mathrm{~N} \leqq \mathrm{~N} 0), 1.0(\mathrm{~N}>\mathrm{N} 0)$

KR1およびN0の值は実験結果との整合性より，KR1＝KR0／50，N0 $=118(\mathrm{kN})$ とした。

通し貫（内法貫 - 足固貫）一柱接合部：内法貫 - 足固貫の本体は はり柱要素とし，その両端に，文献8)による通し貫接合部の回転剛 性と降伏モーメントの式による完全弾塑性型の回転バネを設置した。

地覆土台：地覆土台の効果は小さいことから, 両端ピンのはり柱 要素とした。

傾斜復元力 : 傾斜復元力は, 頭貫一柱接合部位置に頭貫軸方向に 並列して設けた軸方向バネとしてモデル化した。バネの特性は既往 の文献9），10）を参照して図９のように設定した。

板壁 : 力板と力貫それぞれの本体ははり柱要素とし, 要素端部に

図 8 剛性・耐力に及ぼす板壁数量の影響

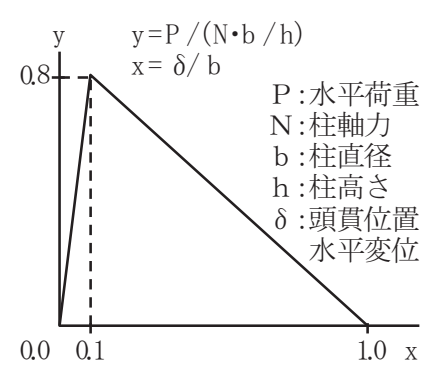

図 9 傾斜復元力のバネの設定

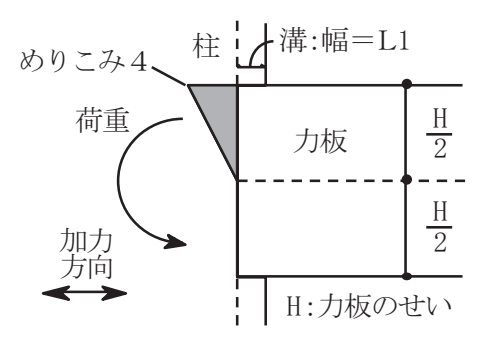

図 10 力板のめり込み状態の設定

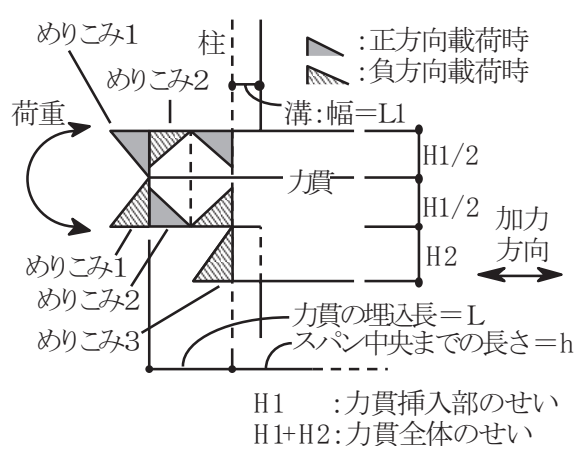

図 11 力貫のめり込み状態の設定 
表 5 力板 $\cdot$ 力貫の諸量

\begin{tabular}{c|c|c|c|c}
\hline \multirow{2}{*}{} & \multicolumn{3}{|c|}{ 力貫 } & 力板 \\
\cline { 2 - 5 } & めり込み 1 & めり込み 2 & めり込み 3 & めり込み 4 \\
\hline \hline $\mathrm{xp}$ & $\mathrm{H} 1 / 2$ & $\mathrm{xp} 1$ & $\mathrm{H} 2$ & $\mathrm{H} / 2$ \\
\hline $\mathrm{x} 1$ & $\mathrm{H} 1 / 2$ & $\mathrm{~L}-\mathrm{xp} 1$ & 0 & $\mathrm{H} / 2$ \\
\hline $\mathrm{x} 2$ & 0 & 0 & 0 & 0 \\
\hline $\mathrm{yp}$ & $\mathrm{t}$ & $\mathrm{t}$ & $\mathrm{t}$ & $\mathrm{t}$ \\
\hline $\mathrm{y} 1$ & 0 & - & 0 & 0 \\
\hline $\mathrm{y} 2$ & 0 & - & 0 & 0 \\
\hline
\end{tabular}

My：回転バネの降伏モーメント

$\mathrm{K}$ ：回転バネの弾性剛性

E : 木材の繊維直交方向の ヤング係数

Fm：木材の繊維直交方向の めり込み降伏応力度

：繊維方向に対する繊維直交方向 の置換係数 $(\mathrm{n}=6)$
表 5 の記号については以下の通りである。

- めり込み $1,3,4$ : 三角形変位めり込みの式 ${ }^{8)}$ にる

$\mathrm{My}=\mathrm{K} \cdot \frac{\mathrm{Z} 0 \cdot \mathrm{Fm}}{\mathrm{xp} \cdot \mathrm{E} \cdot \sqrt{\mathrm{Cx} \cdot \mathrm{Cy} \cdot \mathrm{Cxm} \cdot \mathrm{Cym}}} \quad \mathrm{K}=\frac{\mathrm{xp}^{3} \cdot \mathrm{yp} \cdot \mathrm{Cy} \cdot \mathrm{E}}{\mathrm{Z} 0} \cdot\left(\frac{1}{3}+\frac{2}{3} \cdot \frac{\mathrm{Z} 0}{\mathrm{xp}}\right)$

・めり込み 2 : 掘立柱の式 ${ }^{11)}$ による

$\mathrm{My}=\mathrm{K} \cdot \frac{\mathrm{Z} 0 \cdot \mathrm{Fm}}{\mathrm{xp} 1 \cdot \mathrm{E} \cdot \sqrt{\mathrm{Cx} \cdot \mathrm{Cxm} \cdot \mathrm{Cym}}} \quad \mathrm{xp} 1=\frac{2 \cdot \mathrm{L}^{3}+3 \cdot \mathrm{h} \cdot \mathrm{L}^{2}}{3 \cdot \mathrm{L}^{2}+6 \cdot \mathrm{h} \cdot \mathrm{L}+4 \cdot \mathrm{h} \cdot \mathrm{Z} 0}$

$\mathrm{K}=\frac{\mathrm{yp} \cdot \mathrm{E} \cdot\left\{2 \cdot \mathrm{xp} 1^{2} \cdot \mathrm{Z} 0+\mathrm{xp} 1^{3}+(\mathrm{L}-\mathrm{xp} 1)^{3}\right\}}{3 \cdot \mathrm{Z} 0}$

ただし，

$\mathrm{Cx}=1+\frac{2}{3} \cdot \frac{\mathrm{Z} 0}{\mathrm{xp}} \cdot\left\{2-\exp \left(-\frac{3}{2} \cdot \frac{\mathrm{x} 1}{\mathrm{Z} 0}\right)-\exp \left(-\frac{3}{2} \cdot \frac{\mathrm{x} 2}{\mathrm{Z} 0}\right)\right\}$

$\mathrm{Cy}=1+\frac{2}{3} \cdot \frac{\mathrm{Z} 0}{\mathrm{n} \cdot \mathrm{yp}} \cdot\left\{2-\exp \left(-\frac{3}{2} \cdot \frac{\mathrm{n} \cdot \mathrm{y} 1}{\mathrm{Z} 0}\right)-\exp \left(-\frac{3}{2} \cdot \frac{\mathrm{n} \cdot \mathrm{y} 2}{\mathrm{Z} 0}\right)\right\}$

$\mathrm{Cxm}=1+\frac{4}{3} \cdot \frac{\mathrm{Z} 0}{\mathrm{xp}} \quad \mathrm{Cym}=1+\frac{4}{3} \cdot \frac{\mathrm{Z} 0}{\mathrm{n} \cdot \mathrm{yp}}$
表 6 解析に用いた諸量

\begin{tabular}{|c|c|c|c|c|c|c|}
\hline 柱 & 径 & 300 & \multirow{8}{*}{$\begin{array}{l}\text { 板 } \\
\text { 壁 }\end{array}$} & \multirow{3}{*}{ 力貫 } & H1 & 75 \\
\hline \multirow{2}{*}{ 頭貫 } & 成 & 210 & & & $\mathrm{H} 2$ & 105 \\
\hline & 幅 & 100 & & & $\mathrm{~L}$ & 60 \\
\hline \multirow{2}{*}{$\begin{array}{c}\text { 内法 · 足固 } \\
\text { 地覆土台 }\end{array}$} & 成 & 180 & & 力板 & $\mathrm{H}$ & 258.75 \\
\hline & 幅 & 90 & & \multirow[b]{2}{*}{ 共通 } & 幅 & 45 \\
\hline \multicolumn{2}{|c|}{$\begin{array}{c}\text { 繊維直交方向 } \\
\text { ヤング係数 } \\
\end{array}$} & 239 & & & $\begin{array}{l}\text { 溝 } \\
\text { 幅 }\end{array}$ & 15 \\
\hline \multirow{2}{*}{\multicolumn{2}{|c|}{$\begin{array}{c}\text { 繊維直交方向 } \\
\text { めり込み降伏強度 }\end{array}$}} & \multirow{2}{*}{ 4. 71} & & \multirow{2}{*}{ ダボ } & 幅 & 21 \\
\hline & & & & & 成 & 21 \\
\hline
\end{tabular}

※木材の定数は材料試験による，単位 長さ： $\mathrm{mm}$, 強度・やング係数 : $\mathrm{N} / \mathrm{mm}$

表 7 各部材の回転バネの定数

\begin{tabular}{c|c|c} 
表 7 & \multicolumn{1}{c}{ 各部材の回転バネの定数 } \\
\hline 部材 & $\begin{array}{c}\text { My } \\
(\mathrm{kN} \cdot \mathrm{mm})\end{array}$ & $\begin{array}{c}\mathrm{K} \\
(\mathrm{kN} . \mathrm{mm} / \mathrm{rad})\end{array}$ \\
\hline \hline 頭貫 & 5474 & $6.553 \times 10^{5}$ \\
\hline 通し貫 & 11680 & $1.546 \times 10^{6}$ \\
\hline 力貫 & 216 & $1.706 \times 10^{4}$ \\
\hline 力板 & 1581 & $1.475 \times 10^{5}$ \\
\hline
\end{tabular}

表 8 ダボのせん断バネの定数

\begin{tabular}{l|c||c|c}
\hline $\mathrm{Pa}(\mathrm{kN})$ & 6.0 & $\mathrm{Ka}(\mathrm{kN} / \mathrm{mm})$ & 6.000 \\
\hline $\mathrm{Pb}(\mathrm{kN})$ & 11.0 & $\mathrm{~Kb}(\mathrm{kN} / \mathrm{mm})$ & 1.667 \\
\hline$\delta \mathrm{a}(\mathrm{mm})$ & 1.0 & $\mathrm{Kc}(\mathrm{kN} / \mathrm{mm})$ & 0.333 \\
\hline$\delta \mathrm{b}(\mathrm{mm})$ & 4.0 & & \\
\hline
\end{tabular}

完全弾塑性型の回転バネを設置した。回転バネの降伏モーメント,

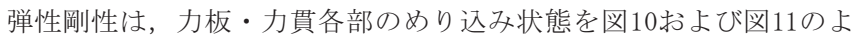
うに仮定して, 文献8)の弾性域におけるめり込み基準式の三角形変 位めり込み式, 文献11)の堀立柱型柱脚部および片側貫接合部の回転 剛性と降伏モーメントの式を適用し, 表 5 に示す諸量を用いて算定 した。また, 力板・力貫の端部には, 板のガタツキを表わす水平方 向軸バネと鉛直方向軸バネを挿入し，実験から得られた経験值とし て, 剛性が水平方向 $\mathrm{kh}=0.1(\mathrm{kN} / \mathrm{mm})$, 鉛直方向 $\mathrm{kv}=10.0(\mathrm{kN} / \mathrm{mm})$ な る弾性バネとした。ダボは，上下の部材のずれに対して抵抗するせ ん断バネに集約してモデル化し，その特性は，図12に示すように， 別途実施したダボ単体の要素実験 ${ }^{12)}$ で得られた標準的なダボの荷重 一変形関係をTri-Linearの折線で模擬した。

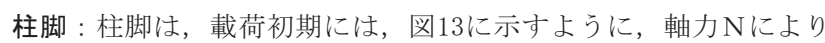
礎石部分に押し付けられ底面が密着した状態（状態 1 ）となり，水 平荷重 $\mathrm{P}$ が増加するに従って点 $\mathrm{B}$ が浮き上がり, 点 $\mathrm{A}$ を支点に剛体 的に回転する状態（状態 2 ） へと移行し, 状態 1 から状態 2 に移行 する間は，柱が完全な剛体ではないために徐々に底面の密着部分が 少なくなっていくものと思われる。柱脚の支持状態は, 概ね, 状態

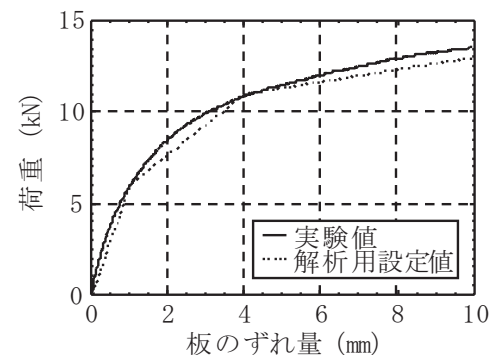

図 12 板壁ダボのバネの特性

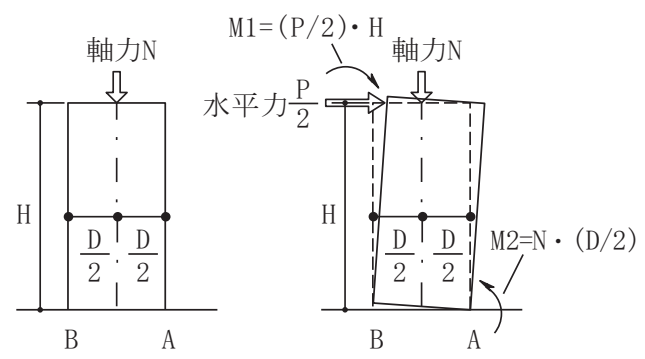

（a）状態 $1(\mathrm{M} 1<\mathrm{M} 2)$ (b) 状態 $2(\mathrm{M} 1>\mathrm{M} 2)$

図 13 想定される柱脚（柱 1 本分）の状態

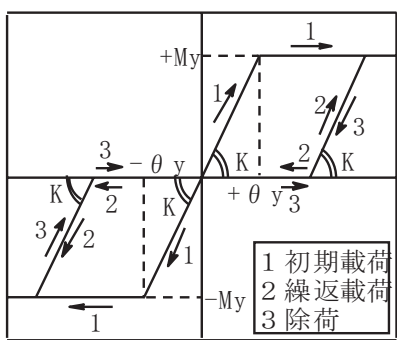

（a）頭貫 · 通し貫 $\cdot$ 力板 $\cdot$ 力貫

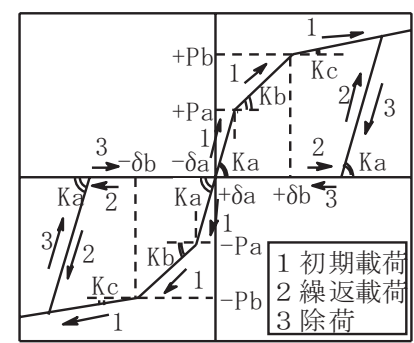

(b) ダボ
図 14 繰り返し載荷時の履歴ルール

1 では固定, 状態 2 ではピン, 状態 1 と状態 2 の間では底面の密着 面積の変化に応じて剛性が変化する半固定状態となるものと思われ るが，ここでは，これを単純化し，図13のモーメントの状態がM1 M2なる範囲では状態 1 に近い固定支持状態, M1>M2なる範囲では状 態 2 に近いピン支持状態，として, $\mathrm{M} 1=\mathrm{M} 2$ に相当する $\mathrm{P}=\mathrm{N} ・ \mathrm{D} / \mathrm{H}(=$ 


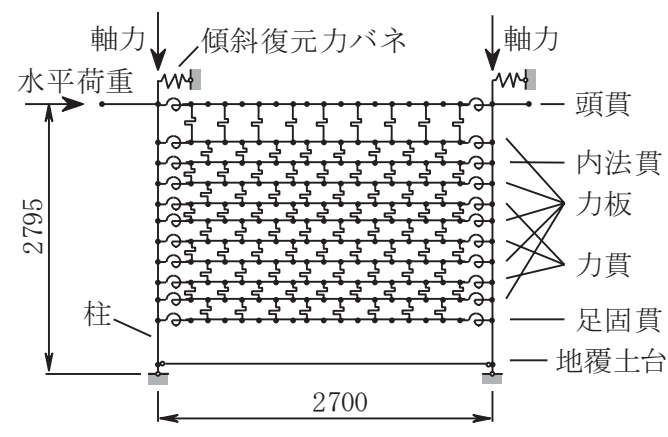

与:せん断バネ $心$ :軸方向バネ・:節点

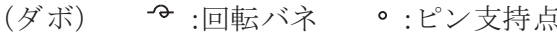

※力貫・力板端部にはがタつきの水平バ䄈挿入

図 15 骨組解析用モデル

4. $72 \mathrm{kN})$ までは柱脚固定, それ以降は柱脚ピンと した。実験結果では, これよりやや高めの荷重 (初 期載荷時で約 $\mathrm{P}=5.8(\mathrm{kN}))$ で荷重一変形関係に折 れ点が見られ, 柱脚の丸ダボへの引掛かりなどが 影響しているものと思われるが，本解析では，計 算值による $\mathrm{P}=4.72(\mathrm{kN})$ を採用した。

繰返載荷時の復元力特性 : 頭貫 - 通し貫 - 力板 . 力貫の回転バネおよびダボのせん断バネの繰り返 し特性は図14のように設定した。表 6 にバネの算 定等に用いた諸量, 表 7 に頭貫 - 通し貫 - 力板 力貫のバネの定数, 表 8 にダボのバネの定数をそ れぞれ示す。

図15に，解析に用いた要素分割とバネ設定位置 を示寸。また, 解析にはハイブリッド型応力法に よる 3 次元立体骨組構造物の弾塑性崩壊解析プロ

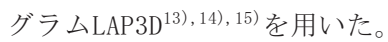

\section{6. 解析結果}

図 $16(\mathrm{a})-(\mathrm{d})$ に, 水平荷重 : P - 変形角 : R 関係 について，実験結果と解析結果とを比較したもの を示す。また, 表 9 には, 変形角 $\mathrm{R}=1 / 30(\mathrm{rad})$ に おける耐力について, 実験結果と解析結果とを比 較したものを示す。解析值の剛性は初期載荷時, 繰返載荷時共に実験值に近い值を示すが荷重值は 計算值の方が若干大きめとなり, 変形角 $\mathrm{R}=1 / 30$ ( $\mathrm{rad}$ ) で $1 \sim 2$ 割程度の差となる。解析值の 方が大きめの值となった理由としては, 実験では 柱など一部の部材を試験体ごとに交換せず使い回 していることなどが影響しているものと思われる。 解析では, いずれの解析対象についても初期載荷 時の変形角 1/120( $\mathrm{rad})$ を越えたあたりから貫 材・板材端部の回転バネの降伏が始まり, 変形角 1/60(rad) ピークまでですべての回転バネが降伏した。また, 初期載 荷時の変形角 $1 / 60(\mathrm{rad})$ を越えるとダボのせん断バネの降伏が始ま るが，板壁の量が少ないほど最終的に降伏しないダボも多く見られ た。なお，はり柱要素でモデル化した部分（バネ以外の部分）は計 算終了まです心゙て弾性範囲内であったが，実験においても接合部で

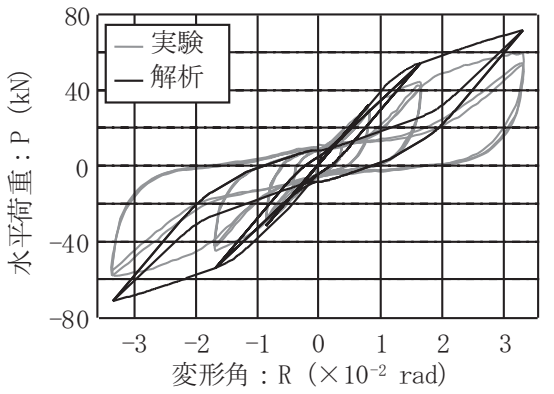

(a) Type7

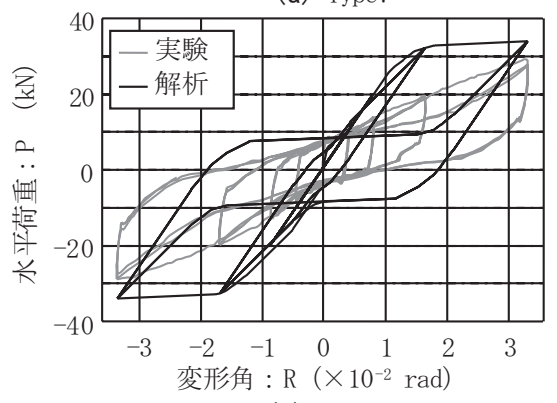

(c) Type10

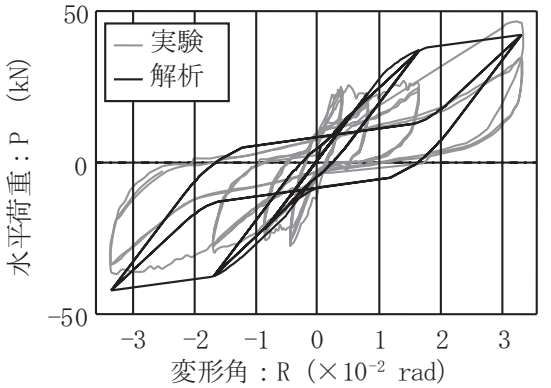

(b) Type9

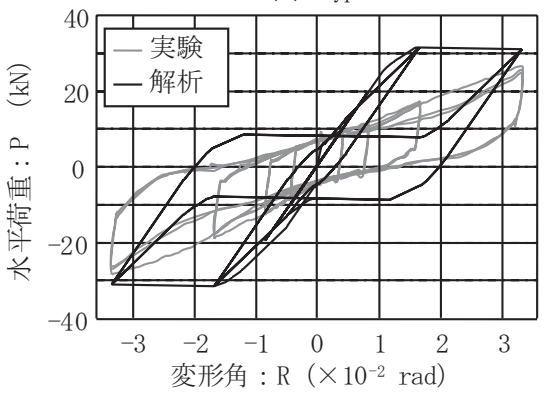

(d) Type11
図 16 実験值と解析值の比較

表 9 解析值と実験值の比較

\begin{tabular}{|c|c|c|c|c|}
\hline \multirow{2}{*}{ 試験体 } & & \multicolumn{3}{|c|}{$\mathrm{R}=1 / 30(\mathrm{rad})$} \\
\cline { 3 - 5 } & & $\begin{array}{c}\text { 解析值 } \\
(\mathrm{kN})\end{array}$ & $\begin{array}{c}\text { 実験值 } \\
(\mathrm{kN})\end{array}$ & 解 $/$ 実 \\
\hline \multirow{2}{*}{ Type7 } & 正載荷 & +70.3 & +58.2 & 1.21 \\
\cline { 2 - 5 } & 負載荷 & -70.3 & -56.3 & 1.25 \\
\hline \multirow{2}{*}{ Type9 } & 正載荷 & +41.5 & +44.0 & 0.94 \\
\cline { 2 - 5 } & 負載荷 & -41.5 & -34.0 & 1.22 \\
\hline \multirow{2}{*}{ Type10 } & 正載荷 & +33.3 & +28.5 & 1.17 \\
\cline { 2 - 5 } & 負載荷 & -33.3 & -28.3 & 1.18 \\
\hline \multirow{2}{*}{ Type11 } & 正載荷 & +30.4 & +26.1 & 1.17 \\
\cline { 2 - 5 } & 負載荷 & -30.5 & -27.8 & 1.10 \\
\hline
\end{tabular}

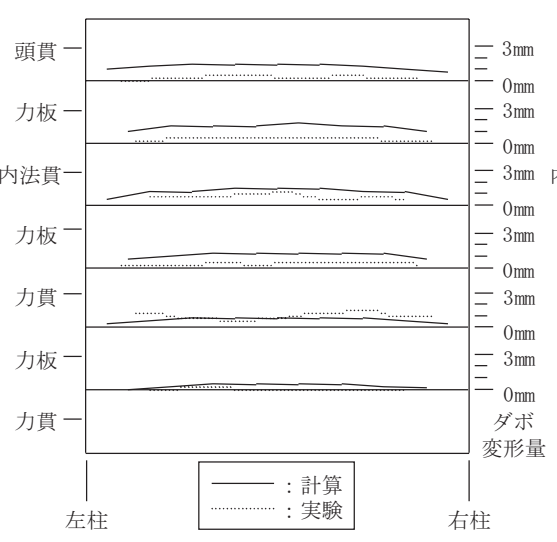

(a) Type9

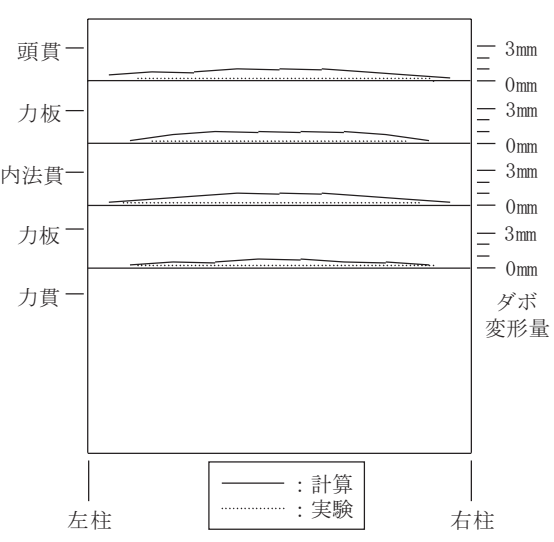

(b) Type10
図 17 ダボの残留変形量の比較

の局部的なめり込みの他は部材断面の割れなどの大きな損傷は見ら れなかった。

次に, ガタつきバネのバネ定数 $\mathrm{kh}, \mathrm{kv}$ の設定值の妥当性の検証デ 一タとして, 実験終了後に解体した試験体のダボの変形量と解析に よるダボのせん断バネの変形量とを比較した。ダボは加力中は板壁 内に埋め込まれていて観察は不可能なため, 実験終了後のダボのせ 
ん断変形量を解析における変形角 $\pm 1 ／ 30(\mathrm{rad})$ の繰り返し載荷終 了後のダボせん断バネの残留変形に相当するものと見なした。図 17 (a)，（b)にダボの変形量について実験結果と解析結果とを比較し たものを示す。全体的に計算結果の変形量が実験結果の変形量より 大きめになる傾向が強いが, 鉛直方向については板壁の上部のダボ の変形が下部に比べて大きくなる傾向や, 水平方向については板壁 中央のダボの変形が端部に比べて大きくなる傾向は, 概ね, 一致し ている。

\section{7. まとめ}

本報告では, 耐震性能の向上を図るためにいくつかの独自の工夫 を施した伝統木造架構について, 実大水平加力実験を行ない, その 影響, 効果を調査した。

本実験で得られた主要な知見を以下に列挙する。

なお,こうした知見は, 架構の仕様については今回提案したもの の採用を前提とするが, 部材寸法や使用する木材の樹種 (材料特性) が異なる場合については，少なくとも定性的には同様な傾向を示寸 ものと思われる。また, 有限要素法を中心とした, 現在の解析的手 法をもってすれば，ある程度の精度で耐力，変形を算定することは 比較的容易であることから, 解析的な検討との併用により, 定量的 にも，設計等で必要な情報を得ることは十分に可能と考える。

1）柱頭に設けたすべり勾配は, 変形に伴う柱の割れの拡がりを抑 え，頭貫と柱を一体化させる効果がある。

2）長押は, 耐震要素として有効に機能し, 長押のない場合に比心゙ て最大で 1.5 倍前後耐力が増加し, 板壁の耐力負担を減らす上で も，その有用性は高い。

3）通し貫（内法貫, 足固貫）については, 貫本数が 1 本増えるご とに約 1.5 倍，耐力が増加する。

4）地覆土台の耐力上の寄与は小さい。

5）板壁は, 耐震要素としてその効果が最も大きく, 板壁のない場 合に比べて，最大で 3 倍前後耐力が増加する。

6）小壁を有する板壁架構では, ダボの本数, 板の枚数に比例して 架構の剛性，耐力も増加寸る。

7）板壁の設置箇所が垂壁, 腰壁と位置が異なる場合でも, 板壁の 数量が同じならば, 架構の耐力, 変形性状はほぼ同様なものとな る。

8）架構全体の繰り返し変形性状は,板壁ダボの有無によって大き く異なり，ダボつきの板壁がある場合には，除荷時・再載荷時に 丸みのあるスリップ性状の荷重-変形関係となり, 除荷時にダボの 抵抗によりある程度の荷重を保持しながら荷重が減少する履歴ル ープとなる。

9）板壁なし, または, ダボなしの板壁の場合には, 再載荷時の耐 力低下の少ないスリップ性状の荷重一変形関係となるが, 除荷時に はダボがある場合よりも急激に荷重が減少する履歴ループとなる。 10）ダボつきの板壁の枚数が少ない場合には, 繰り返しの振幅が 比較的小さい段階（変形角 $\mathrm{R}=1 / 240 \sim 1 / 120(\mathrm{rad})$ 付近まで）では ダボなしの架構に近い履歴ループとなるが，変形が大きくなるに 従ってダボ付き板壁のある架構に近い履歴ループに移行していく。

\section{参考文献}

1）木内, 山田, 貞広, 河内 : 新・耐震化伝統木造架構の実大水平加力実験（そ の 1 ・ 2 ) , 日本建築学会大会学術講演梗概集, C-1分冊, pp. 145〜 $148,1999.9$

2) 菊岡, 森山, 西川, 西澤 : 伝統的木構造における廻廊架構の耐振性能評価に 関する実験的研究（その 2 静的水平載荷実験）, 日本建築学会大会学術 講演梗概集, F-2分冊, pp. 365 366, 2005.9

3）丹羽, 中野：法隆寺金堂の構造に関する研究（その 1 柱と頭貫の縮尺模 型実験), 日本建築学会中国支部研究報告書, 第17巻, pp. 409 412, 1992.3

4) 佐藤, 藤原, 藤田 : 長押の変遷と構造性能に関する実験的研究, 日本建築学 会大会学術講演梗概集, C-1分冊, pp. 413〜 414, 2003.9

5）白鳥, 網野, 小松 : 締直しによる回復機構を持つ「楔一長押」嵌合接合部 の開発・応用研究 多節未成熟間伐材を利用できる千鳥配置列柱耐力壁, 日本建築学会大会学術講演梗概集, C-1分冊, pp. 407 408, 2005.9

6）宮本, 森山, 西川, 西澤: 伝統的木構造における廻廊架構の力学的特性に関 する実験的研究（その 2 耐震性能評価）, 日本建築学会大会学術講演梗 概集, F-2分冊, pp. 389〜390, 2007.8

7）（財）日本住宅・木材技術センター：「土塗り壁・面格子壁・落とし込み 板壁の壁倍率に係る技術解説書」, 土塗り壁等告示に係る技術解説書作成 編集委員会, 2004

8）稲山：めり込夕抵抗接合の設計 (貫構造), 建築技術, pp. 106 111, 1995. 11

9）河合：古代木造建築の柱傾斜復元力と耐力壁の効果に関寸る実大実験, 日本建築学会大会学術講演梗概集, 構造 (2) 分冊, pp. 1021 1022, 1993.9

10）軽部, 林, 原田, 高橋, 木村：古代伝統木造架構の実大水平加力実験 その 2 実大架構実験と履歴性状, 日本建築学会大会学術講演梗概集, C-1分 冊, pp. 269〜270, 1998. 9

11）日本建築学会：シンポジウム「木構造と木造文化の再構築」テキス 卜,pp. 100, 2001.3.1

12）河内, 木内, 貞広, 木村, 福本 : 板壁ダボの要素実験, 日本建築学会大会学術 講演梗概集, C-1分冊, pp. 343〜344, 2005. 9

13）稲田, 川端,近藤 : ハイブリッド型応力法による 3 次元立体骨組構造物の 弾塑性崩壊解析プログラム（LAP3D）の開発，日本建築学会技術報告集， 第16号, pp. 73〜 76, 2002. 12

14）稲田, 川端,近藤：ハイブリッド型応力法による半剛接ばね挿入梁・柱要 素の開発について, 日本建築学会大会学術講演梗概集, B-1分冊, pp. 275〜 $276,2000.9$

15）河内, 木内, 貞広, 木村, 福本, 近藤 : ハイブリッド型応力法による 3 次元立 体骨組構造物の弾塑性崩壊解析プログラム（LAP3D）の伝統木造架構への 適用, 日本建築学会技術報告集, 第13巻 第25号, pp. 109 112, 2007. 6

（2012年 2 月10日原稿受理，2012年 9 月 6 日採用決定） 